\title{
Trends in Economic Growth and Unemployment in Slovakia
}

\author{
Sergej Vojtovic, Emília Krajnakova \\ Department of Management and Human Resource Development, University of Alexsander Dubchek in Trencin, Trencin, Slovakia \\ \{sergej.vojtovic \& emilia.krajnakova\}@tnuni.sk
}

\begin{abstract}
This study deals with one of the current and relatively often discussed phenomenon, which accompanies economic and social development in both developed and economically struggling countries; the countries of Central and Eastern Europe being no exception from this pattern. The analysis of unemployment as an economic and social phenomenon and of the trends unemployment shows is conducted in relation to the period of stabilization and relative economic growth, which followed after the transformation of economic systems in countries of Central and Eastern Europe. The main objects of this analysis are primarily trends in the economic development, trends in the job creation, and the impact of direct foreign investments on the unemployment's development.

The economic development of Slovakia serves as a basis for an analysis of the main trends in economic development, the indicators of unemployment rate and their connection to migration of labour force abroad. We presume that the conditions of historical, economic and social development and the process of the integration of Slovak republic into European Union do not significantly differ from similar processes occurring in other countries of Central and Eastern Europe (or in regional integrations such as the Visegrad group or Baltic countries). This presumption allows us to extrapolate gained knowledge and apply it to the conditions present in other countries of Central and Eastern Europe.

Index Terms - employment, economic development
\end{abstract}

\section{Introduction}

Classic approaches clearly dominate when it comes to the explanations for unemployment and the characteristics of its development - economic development (or economic recession) causes decrease (or increase) in unemployment $[1 ; 2]$. In the countries of Central and Eastern Europe it is commonly accepted conclusion that a solution for a problem with unemployment is mainly connected with the inflow of direct foreign investments and economic growth [3; 4; 5]. However, the economic growth in the Central and Eastern European countries (including those which in this period joined European Union) resembled classic concepts concerning the relation between economic development and unemployment only minimally. According to quite a few of the economists even in Western European developed countries it can be observed that the actual development does not necessarily match the classic macroeconomic concepts $[6 ; 7 ; 8$ and others].

It is known that the situation on the labour market can be influenced by more factors and not exclusively by the economic development. Equally as important are political decisions, qualification of labour force, its values and attitudes, flexibility of norms belonging to the labour jurisdiction and flexible forms of employment, demographic swings in population, employee relations and social aspects within their implementation etc. $[9 ; 10 ; 11]$. In addition, also the interpretation of the reasons causing unemployment remains questionable, as well as factors, which have an impact on unemployment, effectiveness of measures proposed and implemented within state policy of employment and so on [12; 13; and others].

The courses of economic development in the countries of Western, Central and Eastern Europe significantly differ from each other. While countries of Central and Eastern Europe had to transform their economies from centrally planned to market economies, Western European countries have been practicing market economy for much longer period of time. In addition to the revolutionary changes in Central and Eastern Europe there are also the evolutionary ones - involvement of not only equity capital but of the external investments as well, and the influence of not only internal economic factors and political decisions but also of external. Therefore it is possible to assume that economic development and trends on the labour market (and unemployment rate) did not simply and linearly mirror tempo of economic development under these difficult economic, social and political conditions, and causal relationship between economic development and unemployment level is much more complex.

The study aims to determine, to what extent economic development influenced unemployment level. These findings apply predominantly to the period of time preceding economic recession, when above mentioned countries were experiencing post-reform stabilization and subsequent economic growth. Solution of the given problem requires analysis of specific connections between trends in economic development and trends on the labour market including unemployment levels. Accordingly, the main objects of analysis are trends in the unemployment level and factors which could potentially have an impact on them: economic growth, inflow of foreign capital, offers of new jobs etc.

Main goal of the article is to determine, to what extent economic development influences unemployment rate in the period following post-reform stabilization and consecutive economic growth.

Following research methods have been used: theoretical analysis of macroeconomic indicators of economic development, of the trends in the unemployment levels, analysis of statistical indicators of unemployment rate and migration flows of labour force abroad; correlation analysis. 
Scientific originality of the article lies in definition of new connections between GDP growth and unemployment levels. This process was in individual countries influenced by their technological development, infrastructure, qualification of labour force, political decisions and so on. What was the same for all countries was the need for the inflow of foreign direct investments.

\section{Trends in Economic Development}

The most pronounced changes in the Slovak economic development were taking place in the beginning of 1990s. This period brought to a halt relatively technologically advanced fields of industry connected with the manufacturing of military ammunition, which was caused by political decisions without any economic basis. That means that decrease of production in these fields of industry was not a result of falling demand for manufactured products. Simultaneously, a lot of energetically and technologically demanding fields interconnected with mining and primary processing of raw materials came to an end because of their lack of competitiveness on international markets. And exactly during this period a steep rise of unemployment could be observed, which in 1992 reached $11 \%[15]$.

Slovak economy took part in the European integration process and therefore created conditions for inflow of foreign direct investments only after parliamentary elections and political changes in 1998 [15]. Preceding period of eight years after the transformation to market economy could be characterized by economic downfall and following stagnation. In 1998 GDP of the country grew by $4.1 \%$. In this year there were 428 thousand unemployed people, which stood for $16.4 \%$ from the overall number of economically active inhabitants (2.6 mil.). Even though GDP continued to grow in the next year by $1.9 \%$, unemployment rose to $20.1 \%$ [15].

Same trends in the GDP growth apply for the next period. While in 2000 GDP grew only moderately by $1.4 \%$, in the next year GDP growth reached $3.5 \%$. In every consecutive year the dynamics of economic growth accelerated and reached its peak in 2007, when GDP growth reached $10.5 \%$ [15].

\section{Development of Unemployment in the Context of Economic Growth}

The dynamics of development of unemployment level did not match those of GDP. Since unemployment's culmination in 1998 when it peaked at the level of $20.1 \%$, only a moderate decrease and fluctuation between 17 and $19 \%$ can be observed. Steeper decrease in unemployment was documented only after 2005 - in 2005 by $2 \%$, by $3 \%$ in 2006 and by almost $2 \%$ in the two following years, even though the trends in the dynamics of economic growth did not change when compared with previous period (apart from the increase in the tempo of growth by $2.2 \%$ in 2007) (see Table 1).

TABLE I Development of GDP and unemployment rate in Slovak republic (change in \%)

\begin{tabular}{|l|l|l|l|l|l|l|l|l|l|l|l|l|}
\hline & $\mathbf{2 0 0 1}$ & $\mathbf{2 0 0 2}$ & $\mathbf{2 0 0 3}$ & $\mathbf{2 0 0 4}$ & $\mathbf{2 0 0 5}$ & $\mathbf{2 0 0 6}$ & $\mathbf{2 0 0 7}$ & $\mathbf{2 0 0 8}$ & $\mathbf{2 0 0 9}$ & $\mathbf{2 0 1 0}$ & $\mathbf{2 0 1 1}$ & $\mathbf{2 0 1 2}$ \\
\hline GDP $(\%)$ & 3.5 & 4.6 & 4.8 & 5.0 & 6.6 & 8.3 & 10.5 & 5.7 & -4.9 & 4.2 & 3.3 & 2.4 \\
\hline Unempl. (\%) & 19.3 & 18.5 & 17.4 & 18.1 & 16.1 & 13.3 & 11.0 & 9.6 & 12.1 & 14.4 & 13.4 & 13.9 \\
\hline
\end{tabular}

Source: imf.org

Only during the short period 2004-2007 we can observe narrow indirect correlation between GDP growth and unemployment rate. Coefficient of correlation has value -0.99 when $p=0.05$. In preceding period since 2000 to 2004 there was only medium indirect correlation between GDP growth and unemployment rate: $r=-0.54$, when $p=0.01$. Since the occurrence of economic recession in 2008 up until 2012 the correlation between GDP development and unemployment rate is absent almost entirely $(r=-0.07$, when $p=0.01)$. The same can be said for an entire period from 2000 until 2012, because $\mathrm{r}=-0.11$ with $\mathrm{p}=0.06$.

Table 2 depicts the trends in the indicators of GDP development and unemployment rate in other countries of Central and Eastern Europe. For instance, in Baltic countries the economic slump following the beginning of transformation process had little to no influence on a very low unemployment rate, which stays on the level of almost friction unemployment up until 1994. The only exception from this trend is Lithuania, where documented unemployment reached more than $17 \%$. In 1994-1996 and subsequently also at the end of the decade we can observe stable trend of GDP growth in Baltic countries, which fluctuated around 7-10\%. On the other hand, unemployment rose in the period from 1995 to 1997. In Latvia unemployment rose to $18 \%$ during this period, but fell to 6$7 \%$ in 2000. Unemployment rose to $14 \%$ in 90s in Lithuania and Estonia.

Hungarian economic development showed negative tendency only in 1992 and 1993. After 1994 up until 2000 its GDP grew by at least $1.5 \%$, sometimes even by more than $5 \%$. During the period of economic slump unemployment rose to $11.9 \%$, but after the change of the trends in GDP development in 1994 it started to drop, and in 2000 it fell to $6.5 \%$. 
TABLE 2 Development of GDP and unemployment rate in the countries of Central and Eastern Europe (changes in \%)

\begin{tabular}{|c|c|c|c|c|c|c|c|c|c|c|c|c|c|}
\hline & 2000 & 2001 & 2002 & 2003 & 2004 & 2005 & 2006 & 2007 & 2008 & 2009 & 2010 & 2011 & 2012 \\
\hline $\begin{array}{l}\text { Czech } \\
\text { Republic } \\
\text { GDP \% } \\
\text { Unempl. \% }\end{array}$ & $\begin{array}{l}4.2 \\
8.8\end{array}$ & $\begin{array}{l}3.1 \\
8.2 \\
\end{array}$ & $\begin{array}{l}2.1 \\
7.3 \\
\end{array}$ & $\begin{array}{l}3.8 \\
7.8 \\
\end{array}$ & $\begin{array}{l}4.7 \\
8.3 \\
\end{array}$ & $\begin{array}{l}6.7 \\
7.9 \\
\end{array}$ & $\begin{array}{l}7.0 \\
7.1 \\
\end{array}$ & $\begin{array}{l}5.7 \\
5.3 \\
\end{array}$ & $\begin{array}{l}3.1 \\
4.4 \\
\end{array}$ & $\begin{array}{c}-4.7 \\
6.7\end{array}$ & $\begin{array}{l}2.7 \\
7.3 \\
\end{array}$ & $\begin{array}{l}1.6 \\
6.7 \\
\end{array}$ & $\begin{array}{l}0.1 \\
7.0 \\
\end{array}$ \\
\hline $\begin{array}{l}\text { Hungary } \\
\text { GDP } \% \\
\text { Unempl. \% }\end{array}$ & $\begin{array}{l}4.2 \\
6.0 \\
\end{array}$ & $\begin{array}{l}3.7 \\
5.6 \\
\end{array}$ & $\begin{array}{l}4.5 \\
5.9 \\
\end{array}$ & $\begin{array}{l}3.9 \\
5.5 \\
\end{array}$ & $\begin{array}{l}4.8 \\
6.3 \\
\end{array}$ & $\begin{array}{l}4.0 \\
7.3 \\
\end{array}$ & $\begin{array}{l}3.9 \\
7.5 \\
\end{array}$ & $\begin{array}{l}0.1 \\
7.7 \\
\end{array}$ & $\begin{array}{l}0.9 \\
8.0 \\
\end{array}$ & $\begin{array}{r}-6.8 \\
10.0\end{array}$ & $\begin{array}{l}1.2 \\
11.2\end{array}$ & $\begin{array}{l}1.7 \\
10.9\end{array}$ & $\begin{array}{c}0.0 \\
11.5\end{array}$ \\
\hline $\begin{array}{l}\text { Estonia } \\
\text { GDP \% } \\
\text { Unempl. \% }\end{array}$ & $\begin{array}{l}10.0 \\
13.7 \\
\end{array}$ & $\begin{array}{l}7.5 \\
12.6 \\
\end{array}$ & $\begin{array}{l}7.9 \\
10.2 \\
\end{array}$ & $\begin{array}{l}7.8 \\
10.0 \\
\end{array}$ & $\begin{array}{l}6.3 \\
9.6 \\
\end{array}$ & $\begin{array}{l}8.8 \\
7.9 \\
\end{array}$ & $\begin{array}{r}10.1 \\
5.9 \\
\end{array}$ & $\begin{array}{l}7.5 \\
4.6 \\
\end{array}$ & $\begin{array}{r}-3.7 \\
5.5 \\
\end{array}$ & $\begin{array}{r}-3.8 \\
14.2\end{array}$ & $\begin{array}{r}2.3 \\
17.2 \\
\end{array}$ & $\begin{array}{c}7.6 \\
12.5\end{array}$ & $\begin{array}{r}2.0 \\
11.3 \\
\end{array}$ \\
\hline $\begin{array}{l}\text { Latvia } \\
\text { GDP \% } \\
\text { Unempl. \% }\end{array}$ & $\begin{array}{r}6.9 \\
14.6 \\
\end{array}$ & $\begin{array}{c}8.0 \\
13.3\end{array}$ & $\begin{array}{r}6.5 \\
12.1 \\
\end{array}$ & $\begin{array}{r}7.2 \\
10.7 \\
\end{array}$ & $\begin{array}{r}8.7 \\
10.6 \\
\end{array}$ & $\begin{array}{r}10.6 \\
8.8 \\
\end{array}$ & $\begin{array}{r}10.5 \\
6.9 \\
\end{array}$ & $\begin{array}{l}9.6 \\
6.2 \\
\end{array}$ & $\begin{array}{r}-3.3 \\
7.8 \\
\end{array}$ & $\begin{array}{c}-17.7 \\
7.3 \\
\end{array}$ & $\begin{array}{r}-0.3 \\
18.9\end{array}$ & $\begin{array}{c}5.5 \\
15.6\end{array}$ & $\begin{array}{c}2.0 \\
15.5\end{array}$ \\
\hline $\begin{array}{l}\text { Lithuania } \\
\text { GDP } \% \\
\text { Unempl. } \%\end{array}$ & $\begin{array}{r}3.2 \\
16.4 \\
\end{array}$ & $\begin{array}{r}6.7 \\
17.4 \\
\end{array}$ & $\begin{array}{r}6.8 \\
13.5 \\
\end{array}$ & $\begin{array}{l}10.3 \\
12.4 \\
\end{array}$ & $\begin{array}{r}7.4 \\
11.4 \\
\end{array}$ & $\begin{array}{l}7.8 \\
8.3 \\
\end{array}$ & $\begin{array}{l}7.8 \\
5.6 \\
\end{array}$ & $\begin{array}{l}9.8 \\
4.3 \\
\end{array}$ & $\begin{array}{l}2.9 \\
5.2 \\
\end{array}$ & $\begin{array}{c}-14.8 \\
3.7 \\
\end{array}$ & $\begin{array}{r}1.4 \\
17.8 \\
\end{array}$ & $\begin{array}{r}5.9 \\
15.5 \\
\end{array}$ & $\begin{array}{r}2.1 \\
14.5 \\
\end{array}$ \\
\hline $\begin{array}{l}\text { Poland } \\
\text { GDP } \% \\
\text { Unempl. \% }\end{array}$ & $\begin{array}{r}4.2 \\
16.1 \\
\end{array}$ & $\begin{array}{r}1.2 \\
18.3\end{array}$ & $\begin{array}{r}1.4 \\
19.9 \\
\end{array}$ & $\begin{array}{r}3.9 \\
19.6 \\
\end{array}$ & $\begin{array}{r}5.3 \\
18.9 \\
\end{array}$ & $\begin{array}{r}3.6 \\
17.7 \\
\end{array}$ & $\begin{array}{r}6.2 \\
13.8 \\
\end{array}$ & $\begin{array}{l}6.8 \\
9.6 \\
\end{array}$ & $\begin{array}{l}5.1 \\
7.2 \\
\end{array}$ & $\begin{array}{l}1.6 \\
8.2 \\
\end{array}$ & $\begin{array}{l}3.9 \\
9.6 \\
\end{array}$ & $\begin{array}{l}4.3 \\
9.6\end{array}$ & $\begin{array}{l}2.6 \\
9.4\end{array}$ \\
\hline $\begin{array}{l}\text { Slovakia } \\
\text { GDP \% } \\
\text { Unempl. \% }\end{array}$ & $\begin{array}{r}1.4 \\
18.7\end{array}$ & $\begin{array}{r}3.5 \\
19.3\end{array}$ & $\begin{array}{r}4.6 \\
18.5\end{array}$ & $\begin{array}{r}4.8 \\
17.4\end{array}$ & $\begin{array}{r}5.0 \\
18.1\end{array}$ & $\begin{array}{r}6.6 \\
16.1\end{array}$ & $\begin{array}{r}8.3 \\
13.3\end{array}$ & $\begin{array}{l}10.5 \\
11.0\end{array}$ & $\begin{array}{l}5.7 \\
9.6\end{array}$ & $\begin{array}{l}-4.9 \\
12.1\end{array}$ & $\begin{array}{r}4.2 \\
14.4\end{array}$ & $\begin{array}{r}3.3 \\
13.4\end{array}$ & $\begin{array}{r}2.4 \\
13.9\end{array}$ \\
\hline
\end{tabular}

Source: imf.org

Economic development of Poland differs from previously discussed countries. It did not face any negative development of GDP from 1992 to 2001, when it constantly grew by minimally $2.6 \%$ in 1992 and maximally by $6.8 \%$ in 1997 . Following three years brought period of more than $4 \%$ GDP growth. Polish GDP even managed to grow by $1.2 \%$ in 2009 after the outburst of global economic recession. When it comes to the development of unemployment, it grew from $13.3 \%$ in 1992 to $14.4 \%$ in 1994. But in the following years we can observe a moderate decrease to $12.5 \%$ in 1999 and even to $6.7 \%$ in 2000 .

Overall, we can conclude that there was almost no indirect correlation between indication of economic growth and unemployment rate in analysed countries. Noticeable correlation between GDP development and unemployment can be observed only in cases of Hungary Lithuania $\left(r_{H}=-0.65\right.$ and $r_{L}=-0.52$, when $p=0.05$ ). As far as economic development of Poland, Latvia and Estonia is concerned, it can be noted that there was only a minor indirect correlation $(\mathrm{r}$ $=-0.23,-0.29$ and -0.23 when $\mathrm{p}=0.01,0.05$ and 0.05 ) between development of GDP and unemployment during analysed period. Even weaker correlation can be observed in cases of Czech Republic and Slovakia $(r=-0.14$, when $\mathrm{p}=$ 0.01 and $r=-0.11$, when $p=0.06$ ).

Reasons for these differences in economic development in these countries probably cannot be the same for all of them. Their determination would demand deeper analysis of economic and social conditions specific for each country. But even this quick look at the development of such close countries as are Czech Republic and Slovakia indicates that economic development and unemployment rate showed different trends during analysed period.

\section{Results and Conclusions}

Conducted analysis of the influence of economic growth on the employment rate shows that expected narrow indirect correlation between GDP growth and unemployment rate is absent. While GDP growth was accompanied by proportional employment growth and unemployment drop in the previous period, this soundness stops to apply in the conditions of economic growth caused by the DFI inflow. As a result narrow correlation between GDP growth and decrease of unemployment rate is missing. If this trend continued to apply and was further confirmed by other findings, it would require a specification of classical macroeconomic concept of economic theory, which explains relationship between GDP and employment. Simultaneously, it would also be necessary for the government economic and employment policy to change the rules and proceedings applying to the way, how specific measures are created and taken [16]. Assuming that GDP growth does not solve unemployment problem, the change in the principles of state employment policy is called for along with planning of such measures, which would be effective in the process of solving unemployment problems and which would eliminate its negative impacts on economic and social development

Therefore the assumption that economic growth automatically solves unemployment cannot be applied in the present conditions. Current economic production is based on modern and highly efficient technologies, which do not require a lot of labour force. As a result, the economic growth is not influenced by the involvement of bigger amount of labour force. Precisely this situation characterizes economic development not only in Slovakia, but also in other countries of Central and Eastern Europe. Increase in the labour efficiency and GDP growth occurs without them being 
accompanied by proportionally adequate employment growth or unemployment drop.

Direct foreign investments bring modern and highly efficient technologies into the countries of Central and Eastern Europe, which do not need a lot of workers. Development of these technologies in economically advanced countries takes places in the conditions characterized by developed economic, technical, transport, logistic and communication infrastructure. Employment in these fields often exceeds the number of employed in the industrial production. The improvement of technologies and the functioning of the economic infrastructure require more employed workers than modern industrial production. Each step in the creation of new technologies usually demands more time than the preceding one, what consequently means employment of more people.

Similar changes occur in the technological development. Progress in technological development shortens life cycle of existing technologies and increases the demand for new ones. That requires higher number of people working in the process of creation of new technologies and adequate economic infrastructure. In addition, the process of professional training and educating qualified workers along with the process of permanent education takes more time and requires higher number of those doing the training and teaching. These activities involve more employed people than the industrial production itself. But the problem is that these activities are mostly either absent or underdeveloped in the countries of Central and Eastern Europe, and economic development is therefore based on the inflow of direct foreign investments and following transfer of already created new technologies, which do not need a lot of workers for their running.

Thus the type of economy based on the transfer of new technologies and not on their creation and advancement will constantly have to face problems with providing employment for people, even in the conditions of economic growth. And it can be observed that in the society with an economy based on the highly efficient technologies, the absence of employment is moved from economic context (work as a means of making a living) into social and psychological context (work as a social status, work as a communication, work as social relations, work as self-appreciation and so on). Therefore the unemployment problem in these conditions cannot be solved by conventional instruments and policies. It requires further and more detailed analysis of this problem and the implementation of economic, legislative and social measures based on this analysis.

That means that economic growth of Slovakia since 2000 to 2007 took place without any distinctive increase in number of employed in domestic economy. Similarly as in 2000, when GDP growth reached $1.4 \%$ and there was 536 thousand unemployed people in the country, in 2007 when GDP growth peaked at $10.5 \%$ there was still half a million of economically active citizens, whose work was excessive. Significant drop in unemployment was caused by migration of labour force abroad, which is supported by the fact that the tempo of migration increase is very similar to the unemployment decrease. Coefficient of correlation between indicators of unemployment rate decrease and increase of number of migrants for work demonstrates very strong dependence during studied period $(\mathrm{r}=-0.974$, when $\mathrm{p}=0.05)$ [17].

These identified trends in the employment and in the migration of workers abroad did not change in any significant way either during economic recession or during following moderate economic growth. Expected return of Slovak citizens working abroad resulting from economic recession did not occur. Only a minor number of workers employed abroad came back to Slovakia during the crisis. Economic recession had impact predominantly on industry and the most of Slovak citizens working abroad, who lack tertiary education, is employed in the field of services and especially in social services. Jobs in these fields were not influenced by crisis in any major way. Therefore the growth in the unemployment rate during economic crisis was caused predominantly by layoffs occurring in domestic economy.

\section{References}

[1] C. R. Mcconnell, S. L. Brue, S.L. Economics, Principles, problems and policies, Irwin McGraw- Hill, 1999.

[2] P. A. Samuelson, W. D. Norghaus, Ekonomie, Praha: Svoboda, 1991.

[3] E. Ivanová, "Foreign Direct Investments and Economic Growth in the Regions of Slovakia“, Social and Economic Revue, vol. 11, no. 1, p. 29-30, 2012.

[4] E. Koišová, E. Masárová, "Differences in the Development of Unemployment and Long-term Unemployment in Slovakia and in the Trenčín region," Social and Economic Revue, vol.8, no. 3, p. 55, 2012.

[5] A. Sileika \& D. Andriusaitiene, "Problems of Identifying and Regulating the Structure of the Labour Market in Depressive Lithuanian Regions,“"Journal of Business Economics and Management, vol. 7, no. 4, pp. 223-233, 2006.

[6] R. Skidelsky, "The End of Neo-Classicism, "The Vienna Review, no. 10, pp. 25-26, 2008.

[7] J. E. Stiglitz, The invisible hand is paralyzed. The New Republic. [accessed 2 Juni 2011]. Available at: http://www.salon.eu.sk/article.php?article=671-neviditelna-ruka-jeorchnuta-esej

[8] H. Strunz, "Modern Approaches do not ... Ghost Light Facing Dark Shadows, "Social and Economic Revue, vol. 11, no. 1, pp. 97-111, 2013.

[9] A. Grenčíková, J. Španková, "Adaptation of Education to Economy Needs, "Sociálno-ekonomická revue, vol. 10, no. 3, pp. 35-39, 2013.

[10] R. Karbach, J.Kútik, Kompendium der Führungskompetenz, "Wien/Berlin: Mercur Verlag, 2012.

[11] S. Ketkar \& P. K. Sett, "Environmental dynamism, human resource flexibility, and firm performance: analysis of a multi-level causal model," The International Journal of Human Resource Management, vol. 21, no. 8, pp. 1173-1206, 2010.

[12] G. Startiene \& R. Remeikiene. "The Influence of Demographical Factors on the interaction between Entrepreneurship and Unemployment, "Engineering Economics, no. 4, pp. 60-70, 2009.

[13] D. Berzinskiene, L. Juozaitiene, "Impact of Labour Market Measures on Unemployment,“ Engineering Economics, no. 2, pp. 186-195, 2011.

[14] J. Habánik, E. Koišova, Regional Economics and Policy. Bratislava: Sprint, 2012.

[15] UPSVAR. [accessed 2 Juni 2012]. Available at: http://www.upsvar.sk/statistiky/nezamestnanost-mesacne-statistiky/ 2002.html? page_id=1273

[16] R. Mirdala, "Stimulation Effects of Fiscal Policies in the European Converging Economies, “ Ekonomicky Casopis, vol. 59, no. 9, pp. 918941, 2011.

[17] Statistics. Štatistický úrad SK, [accessed 24 Juli 2012]. Alaviable at: http://portal.statistics.sk/showdoc.do?docid=9613 